$=$ 原 著 $=$

\title{
食鳥処理場におけるカンピロバクター交差污染状況
}

\author{
藤田雅弘 $* 1, \dagger$ 遠藤健太郎 $* 2$ ・塩 野 雅 孝*1 \\ 森田幸雄 ${ }^{* 3} \cdot$ 朝倉 宏*4 $\cdot$ 山本茂貴*5 \\ $\left(* 1\right.$ 群馬県衛生環境研究所, $* 2$ 群馬県食肉衛生検査所, $* 3$ 東京家政大学, ${ }^{* 4}$ 国立医薬品食品衛生研究所, $* 5$ 東海大学 $)$
}

(受付：平成 28 年5月19日)

（受理：平成 28 年 8 月 12 日）

\section{Campylobacter Prevalence in Broiler Flocks and Cross-Contamination of Carcasses at a Chicken Slaughterhouse}

\author{
Masahiro Fujita ${ }^{* 1, \dagger}$, Kentaro Endo*2, Masataka Shiono*1, \\ Yukio Morita ${ }^{* 3}$, Hiroshi Asakura ${ }^{* 4}$ and Shigeki Yamamoto*5 \\ ${ }^{* 1}$ Gunma Prefectural Institute of Public Health and Environmental Sciences, Kamioki, Maebashi, Gunma 371-0052; \\ Corresponding author \\ ${ }^{* 2}$ Gunma Prefectural Meat Inspection Office, Tamamura, Sawa, Gunma 370-1103 \\ ${ }^{* 3}$ Tokyo Kasei University, Kaga, Itabashi-ku, Tokyo 173-8602 \\ ${ }^{* 4}$ National Institute of Health Sciences, Kamiyoga, Setagaya-ku, Tokyo 158-8501 \\ ${ }^{* 5}$ Tokai University, Shizuoka 424-8610)
}

\begin{abstract}
In this study, we investigated Campylobacter prevalence in chicken fecal samples and crosscontamination of chicken carcass surface samples at a slaughterhouse, with an aim toward the production of Campylobacter-free chicken meat. Twenty-four broiler flocks comprising a total of 120 chickens were examined. C. jejuni were isolated in fecal samples from 34 chickens (28.3\%) in 12 flocks, and C. jejuni and C. coli were from 5 chickens (4.2\%) in a flock, respectively. A total of 13 Campylobacter-positive flocks and 11 Campylobacter-free flocks existed in this research. Immediately after all Campylobacter-free flocks had been slaughtered, no Campylobacter could be detected from the chicken carcass surfaces. However, all slaughtered flocks, including those that were initially Campylobacter-free, were later found to have been cross-contaminated by Campylobacter-positive flocks slaughtered on the same day. Our results indicate that preventing crosscontamination from Campylobacter-positive flocks is a crucial consideration for chicken slaughterhouse to produce Campylobacter-free chicken meat.
\end{abstract}

Key words: broiler flocks, Campylobacter, chicken carcass, chicken slaughterhouse, cross contamination

\section{緒言}

2015年のわが国の食中毒のうちカンピロバクターに よるものは発生件数の $26.5 \%$ (318/1,202件)，患者数の

†連絡先

*1 焉371-0052 前橋市上沖町 378

*2 䧟370-1103 群馬県佐波郡玉村町樋越 305-7

*3 函173-8602 東京都板橋区加賀 1-18-1

*4 寀158-8501 東京都世田谷区上用賀 1-18-1

*5 远 424-8610 静岡市清水区折戸 3-20-1
9.2\% (2,089/22,718)である. この発生件数, 患者数はと もにノロウイルス食中毒に次いで第2 位であり, 本食中 毒の発生を減少させることは食品衛生上重要な課題であ る.

カンピロバクターの本来の生息場所は家畜・家禽の腸 管内であり，我が国の牛および鷄は主にC. jejuniを， 豚はC. coliを保菌している $1,8,10,11,13)$. 現在, 牛や豚のと 畜処理については， と畜場法関連法令の改正によって, と体に直接接触する機械や器具は 1 頭を処理するごとに $83^{\circ} \mathrm{C}$ 以上の温湯で洗浄・消毒することなどや，牛につい 
ては腸管からの腸内容の漏出による枝肉への污染を防ぐ 目的として, 肍門扔よび食道の結紮が行われているとと もに，枝肉に腸内容が漏出した際には污染箇所のトリミ ングが行われている。 また，牛や豚のレバーや胆汁には カンピロバクターに加え, 腸管出血性大腸菌を保菌して いるものもあることから ${ }^{36,12,15)}$ ，現在は牛・豚レバーの 生食は禁止されている。一方，鷄は食鳥処理場での連続 処理による脱羽や内臟摘出・内外洗浄時等に腸内容物が と体へ付着することなどによるカンピロバクター污染が 少なからず生じてしまう ${ }^{10,11,14) .}$

今日，カンピロバクター食中毒の制御のため, 䳕肉の カンピロバクター污染を減少させることが食品衛生上急 務である。

食鳥処理場搬入前の農場段階でカンピロバクター污染 䳕群と非污染鷄群を調べ, 食鳥処理場ではカンピロバク ター污染觅群を先に処理し, 次に非污染鶏群を处理する ことを区分処理という．2009年に示された，食品安全 委員会の「微生物・ウイルス評価書 鷄肉のカンピロバ クター・ジェジュニ/コリ」(http://www.fsc.go.jp/ hyouka/hy/hy-hyo2-campylobacter_k_n.pdf）（以下「食 品安全委員会評価書」) によると，区分処理を行うこと で鶏肉のカンピロバクター污染を低減する効果が示され ている.

今回，区分処理の効果を確認するため，食鳥処理場に 搬入される鶏群に扔ける盲腸便の検查結果から污染鷄 群・非污染䳕群を定め, その处理と体の拭き取り調査に より，污染群からの交差污染が生じるのか，その実態を 調查した。また，盲腸内抢よびと体の拭き取りから分離 したカンピロバクターはPolymerase Chain ReactionRestriction Fragment Length Polymorphism (PCRRFLP) を実施して遺伝子型を確定し，污染の関連性に ついて調査した。

\section{材料および方法}

\section{調査日 $\cdot$ 調査回数 $\cdot$ 処理䳕群等}

2012 年 5 月に 4 回 (5月 10 日，14日，24日，31日），7 月に 3 回（7月10日，17日，26日）抒よび10月に 2 回 （10月16日，30日）の計 9 回，I〜XVIIの 17 の養䳕場か ら 24 群の鷄が処理された. I, III, VIII, X, XIII, XIV, XV の 5 養鷂場は 2 回, ほかの 12 養鶏場は 1 回処理された.

\section{搬入䳕群の盲腸便および処理と体の拭き取り検査}

検体は盲腸便およびと体の拭き取りを用いた。盲腸便 は搬入鶏群ごとに 5 羽の盲腸便を内臟摘出時に採取し た。採取した盲腸便 $1 \mathrm{~g}$ は10倍量のPrestonブイヨン （Oxoid）に加えて，増菌培養を行った。体の拭き取り は「食鳥処理場におけるHACCP方式による衛生管理指 針」 $(1992)^{4)} に$ 記載された方法で「脱羽後」「「内臟摘出 後」ならびに「チラー通過後」に行い，処理する鶏群が 切り替わるごとにと体胸部を拭き取った。拭き取り検体 は同一群の 3 羽のと体胸部 $(5 \times 5 \mathrm{~cm})$ を各々滅菌ガーゼ
Table 1. Isolation of Campylobacter spp. from samples and flocks

\begin{tabular}{lcc}
\hline \multirow{2}{*}{ Species } & \multicolumn{2}{c}{ Cecal feces: 120 samples, 24 flocks } \\
\cline { 2 - 3 } & $\begin{array}{c}\text { No. of positive } \\
\text { samples (\%) }\end{array}$ & $\begin{array}{c}\text { No. of positive } \\
\text { flocks (\%) }\end{array}$ \\
\hline $\begin{array}{l}\text { C. } \text { jejuni } \text { only } \\
\text { C. jejuni and C. coli }\end{array}$ & $34(28.3)$ & $12^{1)}(50.0)$ \\
\hline Total & $59(42)$ & $1^{2)}(4.2)$ \\
\hline 1) III-1, III-2, VIII-1, VIII-2, IX, X-1, X-2, XII, XIV-1, XIV-2, \\
XV-1, XV-2. \\
2) XIII-2.
\end{tabular}

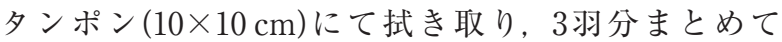
$30 \mathrm{~m} l$ の PBSに浮遊させた後, その拭き取り液 $10 \mathrm{ml} 2$ 倍濃度Prestonブイヨンに加えて, $42^{\circ} \mathrm{C}, 24$ 時間, 微好 気条件下で増菌培養を実施した。

盲腸便検体・拭き取り検体ともに培養したPreston ブ イヨンの1白金耳をButzler 培地 (Oxoid) およびmCCDA (Oxoid) に塗抹後, $42^{\circ} \mathrm{C}, 48$ 時間, 微好気培養を行った. カンピロバクター類似集落（Butzler培地， mCCDA と もに露滴状光沢ある白色集落）はグラム染色を行いグラ ム陰性, S 字状桿菌を確認後, カンピロバクター LA （デンカ生研）で㠜集を確認したものをカンピロバク ター属とした．さらにアピヘリコ（ビオメリュー）拉よ びKlena ${ }^{4)}$ の multiplex-PCRを実施し，菌種の同定を 行った.

\section{PCR-RFLP法による分離菌株の遺伝子型別法}

分離したカンピロバクターからのDNAの抽出は $1 \mu l$ 用のプラスチック製デイスポーザブル白金耳で集落をか き取り，500 $\mu l$ の滅菌超純水（ニッポンジーン）に浮遊 させ， $95^{\circ} \mathrm{Cで} 10$ 分間加熱後，水上で冷却した。 それを $14,000 \mathrm{~g}$ で 10 分間遠心分離し，上清をテンプレートとし た.PCRは, GoTaq Master Mix (Promega)を使用し, Wassenaarらのプライマー ${ }^{16)}$ を用いて flagellin A 遺伝 子を増幅した。増幅した $\mathrm{PCR}$ 産物は $2 \%$ アガロース $\mathrm{S}$ (和光純薬工業) で電気泳動後, 単一なバンドを確認し た. RFLPはNachamkin らの方法 ${ }^{8)}$ に準拠した. PCR 産物 $20 \mu l$ 当たり 1 単位の Dde (Roche) およびHinfI (Roche)で切断し，3\% Nusieve GTGアガロースゲル (Lonza)で電気泳動し, 切断されたDNAのバンドの出 現パターンを観察・記録・比較した。

\section{成 績}

\section{処理鶏のカンピロバクター保菌状況}

処理された鶏の盲腸便 120 検体中 34 検体 (28.3\%) から C. jejuniのみが, 5 検体 $(4.2 \%)$ から C. jejuni と C. coliの 両菌種が検出された，処理鵎群ごとにみると 24 群中 12 群 $(50.0 \%)$ からC. jejuniの みが, 1 群 $(4.2 \%)$ からはC. jejuni と C. coliが検出された (Table 1). 盲腸便からカ ンピロバクターが分離された群を污染鶏群とすると，13 

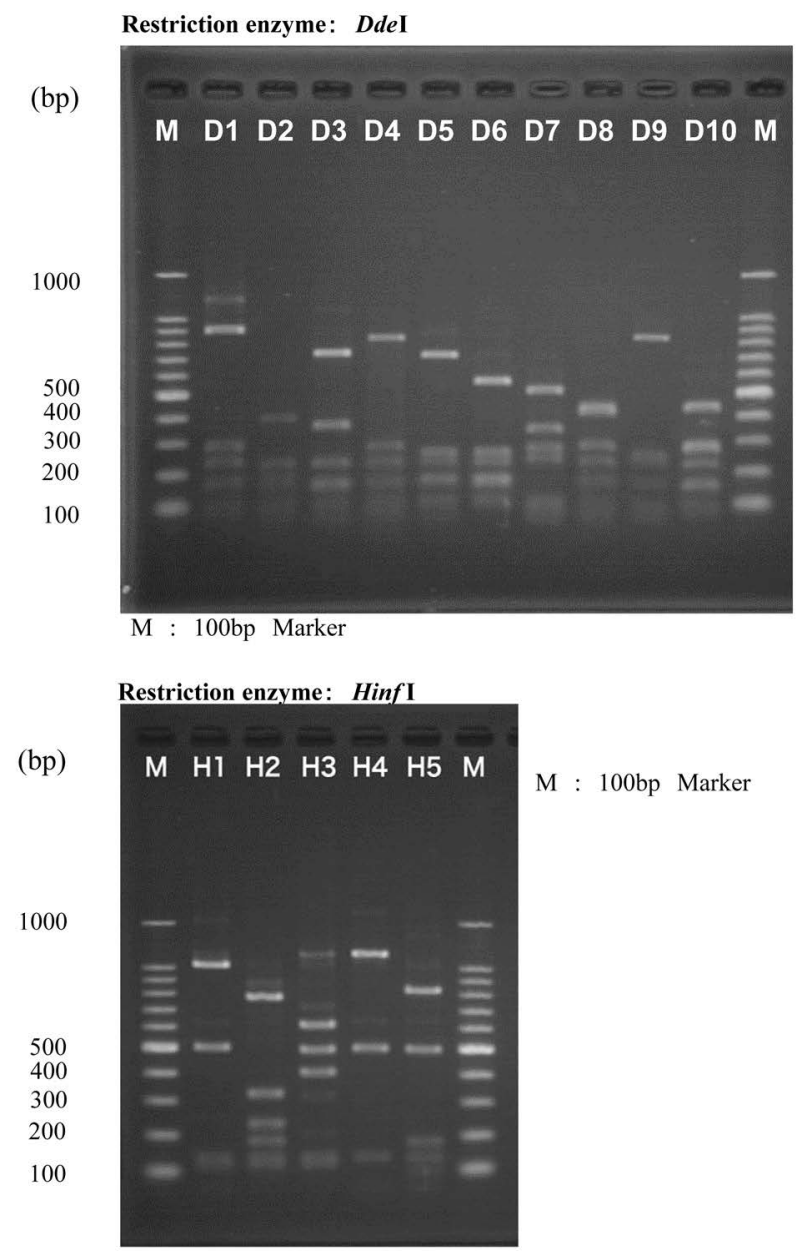

Fig. 1. PCR-RFLP Pictures of restriction enzyme DdeI and HinfI

群, 8 養彩場 (III-1, III-2, VIII-1, VIII-2, IX, X-1, X-2, XII, XIII-2, XIV-1, XIV-2, XV-1, XV-2)が該当した。そのうち C. jejuni と C. coliの両菌種が分離された養鷄場はXIII-2 で，その他の養舀場はC. jejuniのみが分離された。一 方, 盲腸便からカンピロバクターが分離できない群を非 污染鷄群とすると非污染鷄群は 11 群, 10 養鵎場 (I-1, I-2, II, IV, V, VI, VII, XI, XIII-1, XVI, XVII)が該当した．養 鵎場XIII 7 月 26 に 2 群が処理されたがXIII- 1 は非污染 鶏群, XIII-2 は污染鶏群であった。

\section{分離 C. jejuniのPCR-RFLP法による遺伝子型}

盲腸便およびと体の拭き取り検体から分離された $C$. jejuniについてPCR-RFLPを行った．制限酵素D deIの切 断パターンは $\mathrm{D} 1 \sim \mathrm{D} 10$ の 10 パターン, 制限醳素 Hinf $\mathrm{f} の$ 切断パターンはH1〜H5の 5 パターンであった (Fig. 1). この二つの制限酵素による切断パターンの組合せによっ て Table 2のと抢り A〜Nの14の遺伝子型に型別した.

搬入群ごとの盲腸便および拭き取り検体からの検出菌 種または検出 C. jejuni 遺伝子型 (Table 3)

盲腸便から 14 種, 脱羽後と体から 11 種, 内臟摘出後 と体から 10 種, チラー通過後と体から 4 種のC. jejuni 遺伝子型が検出された. C. coliは 7 月 26 日に処理した
Table 2. PCR-RFLP typing by using 2 kinds of restriction enzyme

\begin{tabular}{ccccccccccc}
\hline $\begin{array}{c}\text { DdeI } \\
\text { typing }\end{array}$ & & & & & & & & & & \\
$\begin{array}{c}\text { HinfI } \\
\text { typing }\end{array}$ & D1 & D2 & D3 & D4 & D5 & D6 & D7 & D8 & D9 & D10 \\
\hline H1 & A & C & - & E & - & - & - & J & L & N \\
H2 & - & - & D & - & - & - & - & - & - & - \\
H3 & B & - & - & - & F & H & - & K & - & - \\
H4 & - & - & - & - & G & - & - & - & M & - \\
H5 & - & - & - & - & - & - & I & - & - & - \\
\hline
\end{tabular}

XIII-2 群の盲腸便と脱羽後と体 - 内臓摘出後と体から検 出されたが, チラー通過後のと体からはカンピロバク ターは分離できなかった。

非污染䳕群のみを処理した5月 14 日，5月24日におい ては, 脱羽後と体 - 内臓摘出後と体 - チラー通過後と体 からカンピロバクターは分離できなかった.

污染䳕群のみを処理した5月 51 日，10月16日の脱羽 後と体 · 内臓摘出後と体からカンピロバクターが分離さ れたが, チラー通過後と体からはカンピロバクターは分 離できなかった。

非污染鶏群を先に処理した後に污染䳕群を処理した5 月 10 日，7月 26 日および 10 月 30 日では, 非污染鷄群の脱 羽後と体 . 内臓摘出後と体 · チラー通過後と体からカン ピロバクターは分離できなかった. しかし, その後に処 理した污染鶏群の脱羽後と体 ・内臓摘出後と体・チラー 通過後と体の多くからカンピロバクターが分離された.

污染䳕群を先に処理した後に非污染鵎群を処理した 7 月 10 日および7月 17 日では, 污染䳕群だけでなく非污 染鵎群の脱羽後と体・内臟摘出後と体からカンピロバク ターが分離された。

分離 C. jejuniの遺伝子型では, 13 の污染䊿群のうち 6 群が複数の遺伝子型を, 7 群が一つの遺伝子型を保有し ていた. 污染䳕群では, 盲腸便から分離された遺伝子型 のいずれかがと体拭き取り検体から分離された例が 11 群あった. 污染鷄群を先に処理した後, 非污染鶏群を処 理した7月 10 日では最後（3群目）に処理された非污染 鵎群 $(\mathrm{XI})$ のと体拭き取り検体から, 最初に処理した污 染䳕群 (X-1)のA型と2番目に処理した污染䳕群 (III-2) のE型が分離された. 同様に, 7 月 17 日では 2 番目に処 理した非污染鵎群(I-2)のと体拭き取り検体から最初に 処理した污染群 $(\mathrm{X}-2)$ の $\mathrm{G}$ 型が分離された.

チラー通過後と体からカンピロバクターが分離された 3 群（7月10日処理のX-1, 7 月 17 日処理のX-2, XII,7月 26 日処理のXIII-2) はいずれも污染鷄群であった. 盲腸 便に保有している PCR-RFLP型と同じ遺伝子型が脱羽 後と体または内臓摘出後と体から検出（13中11検体） されるとともに, チラー通過後と体からも検出（同3検 体）された。 
Table 3. Isolation of Campylobacter spp. and PCR-RELP type of $C$. jejuni from cecal faces and carcass surface samples.

\begin{tabular}{|c|c|c|c|c|c|c|c|c|c|}
\hline \multirow[b]{3}{*}{ Date } & \multirow[b]{3}{*}{ Flock } & \multirow{2}{*}{\multicolumn{2}{|c|}{ Cecal feces }} & \multicolumn{6}{|c|}{ Carcass surface } \\
\hline & & & & \multicolumn{2}{|c|}{ After defeathering } & \multicolumn{2}{|c|}{ After evisceration } & \multicolumn{2}{|c|}{ After final chilling } \\
\hline & & Isolation $^{1)}$ & $\begin{array}{c}\text { Species or } \\
\text { PCRRFLP } \\
\text { type of } \\
\text { C. jejuni }\end{array}$ & Isolation & $\begin{array}{l}\text { Species or } \\
\text { PCRRFLP } \\
\text { type of } \\
\text { C. jejuni }\end{array}$ & Isolation & $\begin{array}{l}\text { Species or } \\
\text { PCRRFLP } \\
\text { type of } \\
\text { C. jejuni }\end{array}$ & Isolation & $\begin{array}{c}\text { Species or } \\
\text { PCRRFLP } \\
\text { type of } \\
\text { C. jejuni }\end{array}$ \\
\hline \multirow[t]{3}{*}{ May 10} & $\mathrm{I}-1$ & - & & - & & - & & - & \\
\hline & II & - & & - & & - & & - & \\
\hline & III-1 & + & $\mathrm{L}, \mathrm{H}$ & + & $\mathrm{L}$ & + & $\mathrm{L}$ & - & \\
\hline May 14 & IV & - & & - & & - & & - & \\
\hline \multirow[t]{3}{*}{ May 24} & $\mathrm{~V}$ & - & & - & & - & & - & \\
\hline & VI & - & & - & & - & & - & \\
\hline & VII & - & & - & & - & & - & \\
\hline \multirow[t]{2}{*}{ May 31} & VIII-1 & + & $\mathrm{D}, \mathrm{N}$ & + & $\mathrm{N}$ & + & $\mathrm{N}$ & - & \\
\hline & IX & + & $\mathrm{L}$ & + & $\mathrm{L}, \mathrm{N}$ & + & $\mathrm{L}, \mathrm{N}$ & - & \\
\hline \multirow[t]{3}{*}{ July 10} & $\mathrm{X}-1$ & + & $\mathrm{A}$ & + & $\mathrm{J}$ & - & & + & $\mathrm{J}$ \\
\hline & III-2 & + & $\mathrm{E}, \mathrm{F}$ & + & $\mathrm{E}, \mathrm{F}$ & + & $\mathrm{E}, \mathrm{F}$ & - & \\
\hline & XI & - & & + & A, E & + & A, E & - & \\
\hline \multirow[t]{3}{*}{ July 17} & $\mathrm{X}-2$ & + & $A, G$ & + & $\mathrm{A}$ & + & $\mathrm{A}$ & + & $\mathrm{A}$ \\
\hline & $\mathrm{I}-2$ & - & & + & G & - & & - & \\
\hline & XII & + & B, E, J & + & $\mathrm{B}, \mathrm{E}$ & + & $\mathrm{B}, \mathrm{E}$ & + & $\mathrm{B}$ \\
\hline \multirow[t]{3}{*}{ July 26} & XIII-1 & - & & - & & - & & - & \\
\hline & XIII-2 & + & C, C. coli & + & C, C. coli & + & C, C. coli & + & $\mathrm{C}$ \\
\hline & XIV-1 & + & I & + & I & + & I & - & \\
\hline \multirow[t]{3}{*}{ Oct. 16} & XV-1 & + & $\mathrm{K}, \mathrm{M}$ & + & M & + & M & - & \\
\hline & XV-2 & + & $\mathrm{N}$ & + & B & + & B & - & \\
\hline & XIV-2 & + & I & + & $\mathrm{I}, \mathrm{N}$ & + & I, N & - & \\
\hline \multirow[t]{3}{*}{ Oct. 30} & XVI & - & & - & & - & & - & \\
\hline & XVII & - & & - & & - & & - & \\
\hline & VIII-2 & + & $\mathrm{N}$ & + & $\mathrm{N}$ & + & $\mathrm{N}$ & - & \\
\hline
\end{tabular}

1) -: Campylobacter spp. negative. + : Campylobacter spp. positive.

\section{考察}

カンピロバクター食中毒における鵎の役割および食品 安全委員会評価書で䳕肉のへのカンピロバクター污染の 軽減対策として推奨されている区分処理の効果を確認す るため今回の実験を実施した。

搬入群ごとに見ると 24 群中 12 群 $(50.0 \%)$ がC. jejuni を, 1 群 $(4.2 \%)$ がC. jejuni と C. coliを保菌していた. わが国の食鳥処理場搬入鶏群調査ではカンピロバクター 保菌率は34〜75\%であり，さらにC. jejuniの保菌率が C. coliよりも高いとの報告がある $18,10,11,13)$ ，われわれの 成績も，過去の報告と同様であり，鶏はC. jejuni食中 毒の污染源となる可能性が高いと考えられた。

非污染鵎群のみを，通常どおり処理した場合には，と 体からカンピロバクターは検出されなかった。このこと から，食鳥処理場に搬入される鵎が污染していない場合 には, 食鳥処理場の機器の清掃・洗浄が適切であれば, 処理場内からカンピロバクターの污染は生じないことが 判明した. これに対して污染鶏群を処理した場合, その
と体からもカンピロバクターが分離されるとともに，そ の直後に処理される非污染䳕群のと体からもカンピロバ クターが分離された。分離株の遺伝子型別では直前に処 理された污染䳕群の盲腸内容物由来株と同一の遺伝子型 を示すものが多かった。このことから, 污染鶏群の盲腸 便中に生息するカンピロバクターが次に処理する䳕群の と体を 2 次污染していることが確認された.

今回の拭き取り検査では, チラー通過後のと体のカン ピロバクターの検出率が低かった. 今回はチラー水の塩 素濃度は測定していなかったが, 処理場のマニュアルで は作業開始の濃度は $150 \mathrm{ppm}$ 以上で作業中は $50 \mathrm{ppm}$ 以 上を保持することになっている。 チラー水の塩素濃度を 適切に保持すればチラー通過後のと体のカンピロバク ター污染を軽減することができると考えられた。

非污染鷄群から処理する，いわゆる区分処理は 2 次污 染防止対策として有効であり ${ }^{2)}$, アイスランド, デン マーク，ノルウェー等では区分処理が実施されている ${ }^{7)}$. 搬入前の養鶏場段階でカンピロバクター非污染鷄群であ るか，污染鶏群であるか判明することは極めて難しい課 
題であるが，食鳥処理場で非污染鵎群を先に搬入・処理 するという区分処理が可能となればカンピロバクター污 染のない衛生的な鶏肉を生産することも可能であること が示唆された。

\section{要 約}

カンピロバクター污染がない食鳥と体を生産すること を目的として，食鳥処理場で処理される鵎の保菌調査お よび処理と体の拭き取り検査を実施した。処理鷄 24 群 中 12 群 $(50.0 \%)$ の搬入鷄 120 羽中 34 羽 $(28.3 \%)$ か ら Campylobacter jejuniが検出された。また，1群(4.2\%) の搬入鶏 5 羽 $(4.2 \%)$ からC. jejuni と . coliが同時に検 出された。鷂群でみると 13 群が污染鶏群, 11 群が非污 染鵎群であった. 1 日の処理で非污染鶏群のみを処理し た場合は，カンピロバクターはと体から分離できなかっ た. しかし，污染䊿群を先に処理すると，と体が污染さ れるとともに，施設を介して，その污染が次に処理され ると体を污染していることが判明した，鶏肉へのカンピ ロバクターの交差污染を防ぐためには区分処理をするこ とが有効であると思われた。

\section{謝 辞}

本研究は厚生労働科学研究補助金（平成 $24 \sim 26$ 年度） 「と畜・食鳥検査における疾病診断の標準化とカンピロ バクター等の制御に関する研究, 分担研究：食鳥処理場 におけるカンピロバクターの制御，研究代表者：山本茂 貴 (平成 24 年度), 朝倉 宏 (平成 $25 \sim 26$ 年度)」に よって実施した。

\section{文献}

1) Chuma, T., Makino, K., Okamoto, K. and Yugi, H.: Analysis of distribution of Campylobacter jejuni and Campylobacter coli in broilers by using restriction fragment length polymorphism of flagellin gene. J. Vet. Med. Sci., 59, 1011-1015 (1997).

2) Hue, O., Le Bouquin, S., Laisney, M. J., Allain, V., Lalande, F. et al: Prevalence of and risk factors for Campylobacter spp. contamination of broiler chicken carcasses at the slaughter. Food microbial., 27, 992-999 (2010).

3) Jeong, K. C., Kang, M. Y., Heimke, C., Shere, J. A., Erol, I. et al.: Isolation of Escherichia coli O157:H7 from the gall bladder of inoculated and naturally-infected cattle.
Vet. Microbiol., 119, 339-345 (2007).

4) Klena, J. D., Parker, C. T., Knibb, K., Ibbitt, J. C., Devane, P. M. et al.: Differentiation of Campylobacter coli, Campylobacter jejuni, Campylobacter lari, and Campylobacter upsaliensis by a multiplex PCR developed from the nucleotide sequence of the lipid A gene $l p x A$. J. Clin. Microbiol., 42, 549-557 (2004).

5）厚生省生活衛生局乳肉衛生課編：モニタリング方法及び 細菌検査法の解説，食鳥処理場における HACCP方式に よる衛生管理指針, p. 31-33, 東京(1992)。

6) Matsumoto, N., Taniwaki, T., Kinuta, M. and Murase, T.: Isolation of Campylobacter jejuni and coliform bacilli from bile and liver obtained from slaughter cattle in Western Japan. J. Food Prot., 71, 1228-1231 (2008).

7）三澤尚明：食鳥処理場に㧍けるカンピロバクター制御法 の現状と課題. 日獣会誌， 65, 617-623 (2012).

8）森田幸雄，壁谷英則，石岡大成，坂脇廣美，長井 章 ら：家畜および市販ひき肉におけるArcobacter, Campylobacter, Salmonellaの分布状況. 日獣会誌，57, 393-397 (2004).

9) Nachamkin, I., Bahachick, K. and Patton, C. M.: Fllagelin gene typing of Campylobacter jejuni by restriction flagment length polymorphism analysis. J. Clin. Microbiol., 31, 1531-1536 (1993).

10）小野一晃：市販鵎肉のカンピロバクター及びサルモネラ 污染状況と分離株の薬剂感受性. 日獣会誌， 67, 442-448 (2014).

11) Ono, K. and Yamamoto, K.: Contamination of meat with Campylobacter jejuni in Saitama. Int. J. Food Microbiol., 47, 211-219 (1999).

12) Rosef, O.: Isolation of Campylobacter fetus subsp. jejuni from the gallbladder of normal slaughter pigs, using an enrichment procedure. Acta Vet. Scand., 22, 149-151 (1981).

13) Sasaki, Y., Tsujiyama, Y., Tanaka, H., Yoshida, S., Goshima, T. et al.: Risk factors for Campylobacter colonization in broiler flocks in Japan. Zoonosis Public Health, 58, 350-356 (2011)

14）清水泰美，星野利得，石岡大成，森田幸雄，黒田 晃 ら：食鳥処理場に打ける細菌污染調査。日獣会誌，51, 608-612 (1998).

15) Stotland, E. I., Edwards, J. F., Roussel, A. J. and Simpson, R. B.: Bacterial microflora of normal and telangiectatic livers in cattle. J. Am. Vet. Med. Assoc., 219, 36-39 (2001).

16) Wassenaar, T. M. and Newell, D. G.: Genotyping of Campylobacter spp. Appl. Environ. Microbiol., 60, 1-9 (2000). 